\title{
Machining Operations on Messassa Wood
}

\author{
Narciso Fernando Bila, Rosilani Trianoski, Márcio Pereira Da Rocha, José Reinaldo Moreira da Silva, \\ Setsuo Iwakiri, Andrade Fernando Egas, and Alberto Fernando Mussana
}

\begin{abstract}
This study aimed to evaluate the effect of machining operations on the surface quality of the messassa wood (Brachystegia spiciformis and Julbernadia globiflora) for use in the furniture industry. The wood cames from Mozambican Miombo Woodland. The following machining operations were performed: planing, shaping, milling, tearing and boring based on technical standard. The wood had a surface quality approval rating above $70 \%$ in all tested machining operations. A perfect surface quality was obtained with a feed speed of $6 \mathrm{~m}^{\mathrm{min}} \mathrm{m}^{-1}$ in planing. Brachystegia spiciformis had easy workability and extremely well performance compared to Julbernadia globiflora. Nevertheless, both wood species have great potential for use in higher value-added products such as furniture and frame production.
\end{abstract}

Keywords: Brachystegia spiciformis,Julbernadia globiflora, surface quality, higher value-added products, planing, shaping, milling, tearing, boring.

\section{Introduction}

The Mozambican furniture industry needs modernization and expansion as well as demand for new and lesser-used woodspecies in the domestic and international market. Therefore, knowledge of the possible applications of wood from the native species is essential, considering the high biodiversity existing in the biomes of Mozambique and the different technological characteristics of timber species. In recent years, there has been a tendency for research in Mozambique to indicate other potential species for wood production by determining their anatomical characteristics (Uetimane et al. 2009 and 2018; Bila et al. 2018), chemistry (Lhate et al. 2010), physical and mechanical properties (Ali et al. 2008; Cristovão et al. 2011), and cutting forces (Lhate and Cristovão 2007). Thus, as in the technological characterization of the species, knowledge about machining evaluation and surface quality of wood is extremely important for their use.

The species Brachystegia spiciformis. Benth and Julbernadia globiflora (Benth.) Troupin commonly known as common messassa and red messassa, respectively, represent the largest availability of commercial timber in the country, with approximately $46 \%$ of the total volume (Magalhães 2018). Such species have the potential to be inserted in different sectors of the timber segment for higher value-added produtcs (DNTF 2017). However, due to the lack of knowledge about the behavior of these species under different machining processes, they are relegated to less noble uses in civil construction. It is noteworthy that the optimization in the use of wood involves the knowledge of its characteristics, as well as it is interaction with different machining operations (Silva et al. 2005; Aguilera and Muñoz 2011).

According to Brown (1998) and Silva (2002), wood machining is the mechanical process that aims to give the desired shape regarding the dimensions and quality of wood products. In addition, Lucas (2004) affirm that machining and it's cause and effect relationships with the variables involved in the process are paramount for positioning against the competition and for the development of a more efficient manufacturing process. Taylor et al. (1999) and Gupta et al. (2019) state that during machining process, different species tend to exhibit distinct behavior due to their inherent wood characteristics, such as density, moisture content, anisotropy, presence of silica and minerals, wood grain and texture, juvenile wood, age, reaction wood, presence of knots, among others.

Wood machining includes various operations such as cutting, planing, sanding, milling, boring and turning, requiring specific machines, which can be manual or automatic, aiming a better appearance on their surfaces facilitating a better application of finishing products (Palermo et al. 2010; Zamarian, et al. 2012). Machining quality can be assessed by calculating normative values for tooth feed (fz) or the presence of surface failures, which are generated as a function of the intrinsic structure of the wood or by the roughness parameters $\mathrm{Ra}, \mathrm{Rz}$ provided by the roughness meter (Silva 2002; Braga 2014). However, it is common to infer the quality of the machined wood surface through the use of ASTM D1666-11 (2011) which consists of assigning grades after visual inspection of some defects such as raised grain, fuzzy grain, torn grain, crushing, chip marks, etc. In this assessment, lower grade numbers describe surfaces that would be acceptable in a manufacturing environment, while higher grades require additional rework, resulting in additional production costs (Hernández et al. 2011).

Thus, the present study aimed to evaluate the behavior of two messassa wood species under machining processes such as planing, shaping (top, side, and winding axial), axial and transverse milling, tearing and boring (pin 
and hinge) in order to contribute to the country's timber sector by disseminating scientific and technological information with a view to adapting these species to furniture production, allied to the issues of better use of tropical wood.

\section{Materials and Methods}

\section{Materials}

Wood from two Mozambican native lesser-used species, Brachystegia spiciformis. Benth (red messassa) and Jubernardia globiflora. Benth (common messassa) whose basic density are $(0.670$ and 0.680$) \mathrm{g}_{\mathrm{cm}}{ }^{3}$ respectively, were used. Tangential planks where obtained from 15 logs of $B$. spiciformis and 12 logs of $\mathrm{J}$. globiflora, of $1500 \mathrm{~mm}$ in length, and width variation based on the diameter of the trees, which ranged from (260 to 550 ) $\mathrm{mm}$. Subsequently, the planks were ripping in a multiple circular saw, into board of size $25 \times 150 \times 650 \mathrm{~mm}^{3}$ and conditioned at temperatures of $20 \pm 2^{\circ} \mathrm{C}$ and $65 \pm 5^{\circ} \mathrm{C}$, with a relative humidity to the moisture content of $12 \pm 2 \%$. Then, 20 samples of each species were randomly selected for machining tests. These samples were selected representative of the intrinsic characteristics of the species with smaller heartwood region, when compared with the sapwood, because generally, the heartwood tends to rot in the core and some samples have heartwood and sapwood, in different proportions. This sampling allowed to test the wood as it is marketed in the country.

\section{Methods}

Machining Operations Tests. The machining operations tests followed ASTM D 1666-11 (2011). The machining parameters used in the operations followed the methodology of Zamarian et al. (2012). It is noteworthy that to avoid the influence of cutting edge wear on the machined surface quality, the sequence of the samples in each operation were randomly selected. With the exception of planing, the average feed speeds presented for the remaining operations were manual and obtained by the ratio of machining offset to the programmed time required to perform. All tests were carried out on the same sample using the following technical machining parameters (Table 1).

Table 1. Machining parameters used for Brachystegia spiciformis and Julbernadia globiflora wood

\begin{tabular}{lccccc}
\hline Machining operation & $\mathrm{Nr}$ & $\mathrm{n}\left(\mathrm{min}^{-1}\right)$ & $\mathrm{D}(\mathrm{mm})$ & $\mathrm{V}_{\mathrm{S}}\left(\mathrm{m} . \mathrm{s}^{-1}\right)$ & $\mathrm{V}_{\mathrm{F}}\left(\mathrm{m} \cdot \mathrm{min}^{-1}\right)$ \\
\hline Planing & 3 & 3445 & 105 & 18.93 & $6.0 ; 15.0$ \\
Top frame & 2 & 8000 & 135 & 56.52 & 0.65 \\
Side frame & 2 & 8000 & 135 & 56.52 & 0.78 \\
Winding axial frame & 4 & 8000 & 90 & 37.68 & 0.50 \\
Tearing & 2 & 3380 & 8 & 1.42 & 2.58 \\
Axial milling & 1 & 27000 & 5 & 7.07 & 0.78 \\
Transversal milling & 1 & 27000 & 5 & 7.07 & 1.38 \\
Pin drilling & 2 & 1735 & $8 ; 10 ; 12$ & $0.73 ; 0.91 ; 1.09$ & 0.50 \\
Hinge drilling & 2 & 1735 & 35 & 3.18 & 0.17
\end{tabular}

Where: $\mathrm{Nr}$. = number of knives; $\mathrm{n}=$ tool holder spindle rotation speed; $\mathrm{D}=$ tool diameter; $\mathrm{Vs}-$ Cutting speed; $\mathrm{V}_{\mathrm{F}}=$ Feed speed.

Planing was performed on an Omil model DES 400 planer, with frequency of $60 \mathrm{~Hz}$. The samples were planed on opposite faces parallel to the grain with each face having distinct feed speed and constant cutting speed (Table 1). Two passes were made on each side with a depth of cut of $0.5 \mathrm{~mm}$

Shaping (top and side frame) were performed on a Invicta model TI-14 router, crosswise and along the grain respectively using a standard cutter shaping LEN-Profile 24. For winding axial frame, a flat forming knife was used and consisted of performing a winding curve parallel to the grain and along the length of the sample as shown in Figure 1.

The tearing test was performed in the same corner on the side where the winding axial frame was made, using a hand-feed Invicta FIC - 15 horizontal drill. Only one rip was made in each sample, whose geometry were $5 \times 8 \times 70 \mathrm{~mm}^{3}$ corresponding to the depth, width and length, respectively.

Axial and transverse milling had dimensions of $7 \times 50$ $x 100 \mathrm{~mm}^{3}$, depth, width and length, respectively, forming an "L" shape. Manual column spindle Makita 3709 machine having $1200 \mathrm{~W}, 127 \mathrm{~V}, 60 \mathrm{~Hz}$ and engine speeds ranging from 8000 to $27000 \mathrm{rpm}$ were used.

Boring tests were carried out in a single hand-feed type Motomil boring machine having $1.735 \mathrm{rpm}$. For pin hole, three twist profile carbon steel drills having diameters $(8,10$ and 12$) \mathrm{mm}$ were used. Three holes for hinge (one through hole and two non-through hole) were also drilled using a $35 \mathrm{~mm}$ diameter drill as shown in Figure 1. 


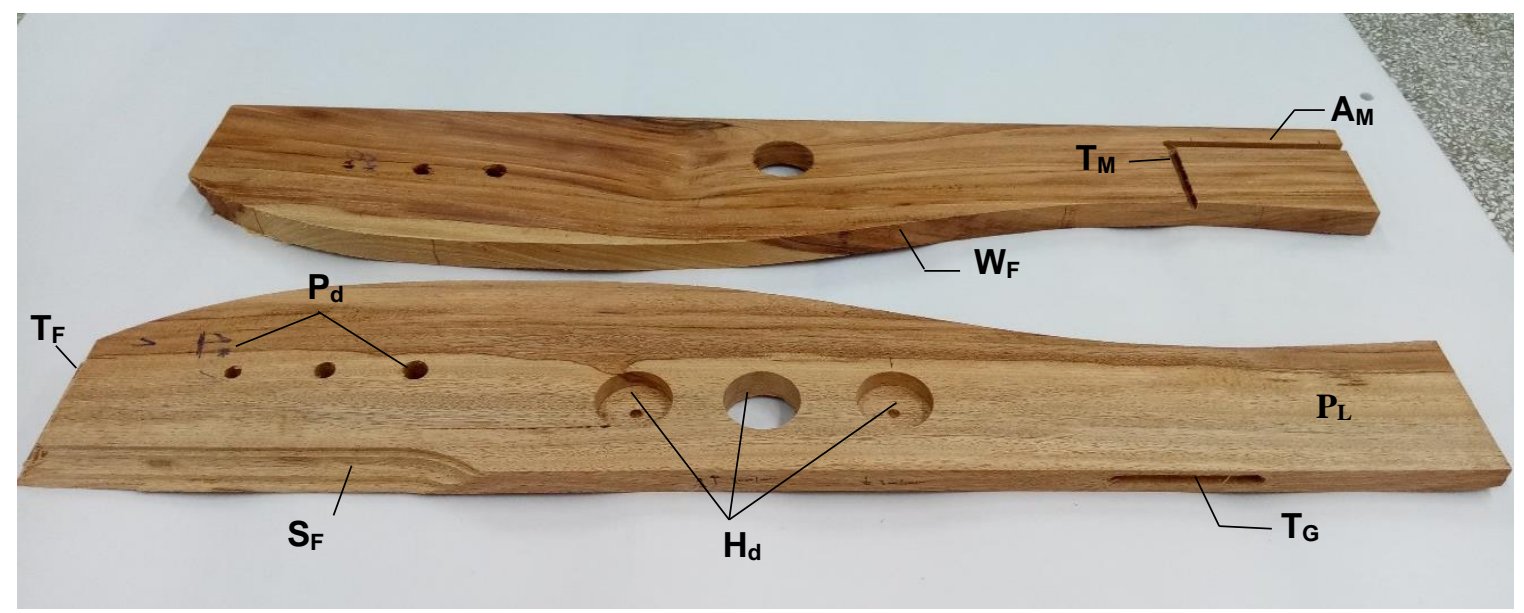

Figure 1. Messassa wood sample in machinig test. $P_{L}-$ Planing; $A_{M}, T_{M}-$ Axial and transversal milling; $T_{F}, S_{F}-T_{o p}$ and side frame; $W_{F}$ - Winding axial frame; $T_{G}-$ Tearing; $P_{d}, H_{d}-$ Pin and Hinge drilling.

Assessment of Machining Operations.The machined wood surface in each operation were visually examined according to ASTM D 1666-11 (2011) on post-machining defects. The examination was made by a team of three evaluators who gave (separately) scores ranging from 1 to 5 in defects according to their intensity and frequency. Defect values were compiled for each operation as a percentage for a given grade. Table 2 summarizes the assignment of defect values used in this study.

Table 2. Quality grades used in determining overall performance for each machining operation

\begin{tabular}{clc}
\hline Grade & \multicolumn{1}{c}{ Surface quality criteria* } & Performance \\
\hline 1 & Surface free of any defects & Excelent \\
2 & Mild to medium raised, torn grain, crushing & Good \\
3 & Strong raised and slight chipped, torn grain, tearouts & Fair \\
4 & Strong raised and mild to medium chipped, torn grain, crushing & Poor \\
5 & Strong raised, chipped, rough-end grain, crushing, tearouts & Very Poor \\
\hline
\end{tabular}
${ }^{\star}$ Adapted from ASTM 1666-11 (2011)

The assigned value allowed grouping the samples into five surface quality grades: Grade 1 (excellent) - no defects in the sample; Grade 2 (good) - presence of less than $50 \%$ of defects; Grade 3 (Fair) - presence of $50 \%$ of defects; Grade 4 (Poor) - presence of more than $50 \%$ of defects and Grade 5 (very poor) - presence of $100 \%$ of defects. Figure 2 illustrates the surface quality grades in planing.

\section{Analysis}

As the purpose of this study was to test the messassa wood for use in products whose surface quality is paramount, such as furniture, frames, doors, windows, among others, the Hotelling $T^{2}$ test was applied to infer the existence of differences between the grades awarded by the evaluators. Then, a single value per surface was determined when at least two of the three evaluators rated a given sample in the same class or by the arithmetic mean when the three assigned different grade without consensus. The correlation between machining operations by Spearman's test was also verified. The results in machining operations were compared based on percentages of samples as grades 1 and 2 .

\section{Results and Discussion}

\section{Machining Test}

Table 3 shows the percentage of surface quality grade in different machining operations for $B$. spiciformis and $J$. globiflora under the specified test conditions. It can be seen that most samples of both species had an approval percentage above $70 \%$ and graded between 1 and 2 corresponding respectively to excellent and good surface quality. However, it is noteworthy that, only in the tearing operation for J. globiflora wood the surface quality was grade 4 . In turn, there was no samples graded 5 for both species throughout the study.

The larger observed number of samples graded 1 and 2 in the different machining operations demonstrates a satisfactory performance of both species, therefore, suitable for use in higher value-added products, such as furniture and frame production. The indication of these species for furniture production, for example, is justified by the good performance in axial, transverse and hinge drilling operations (Table 3). In turn, the indication for frame 
production is supported by the good results in the top, side and winding frame tests.

In Table 3, it can also be seen that for the planing with feed speed of 6 m.min-1 most grades were between 1 and 2. In contrast, the planing with feed speed of $15 \mathrm{~m}^{\mathrm{min}} \mathrm{m}^{-1}$ led to the appearance of defects such as raised, torn and chipped grains, as evidenced by the higher percentage of the samples in grade 3 (fair). Vančo et al. (2017) and Kaplan et al. (2018) also reported for Pinus Sylvestris L. and Oak wood (Quercus cerris) respectively, a decrease in surface quality (increased roughness) as a function of increased feed speed. Thus, these results (table 3) demonstrate the importance of planing this species with low feed speed to ensure a good surface quality, as well as to avoid higher wood consumption during sanding that aims to eliminate waviness and smooth the machined surface of the wood (Silva 2002; Laina et al. 2017). Burdurlu et al. (2005), Hernandez et al. (2001), Ratnasingam and Scholz (2007), and Gupta et al. (2019) state that parameters such as cutting angles and number of knives also have different effects on the quality of the machined wood surface, but were not analysed in the present study.

Table 3. Percentage of samples in each surface quality grade for machined wood of B. spiciformis and J. globiflora

\begin{tabular}{|c|c|c|c|c|c|c|c|c|c|c|c|}
\hline \multirow{3}{*}{$\begin{array}{c}\text { Machining } \\
\text { operation }\end{array}$} & \multirow{3}{*}{ Parameter } & \multicolumn{10}{|c|}{ Grade (\%) } \\
\hline & & \multicolumn{2}{|c|}{1} & \multicolumn{2}{|c|}{2} & \multicolumn{2}{|c|}{3} & \multicolumn{2}{|c|}{4} & \multicolumn{2}{|c|}{5} \\
\hline & & Bs & $J g$ & Bs & $J g$ & Bs & $J g$ & Bs & $J g$ & Bs & $J g$ \\
\hline \multirow{2}{*}{ Planing } & $6 \mathrm{~m} \cdot \mathrm{min}^{-1}$ & 60 & 45 & 25 & 35 & 15 & 20 & 0 & 0 & 0 & 0 \\
\hline & $15 \mathrm{~m} \cdot \mathrm{min}^{-1}$ & 30 & 15 & 25 & 30 & 45 & 55 & 0 & 0 & 0 & 0 \\
\hline Top frame & - & 10 & 5 & 85 & 80 & 5 & 15 & 0 & 0 & 0 & 0 \\
\hline Side frame & - & 85 & 80 & 15 & 15 & 0 & 5 & 0 & 0 & 0 & 0 \\
\hline $\begin{array}{l}\text { Axial winging } \\
\text { frame }\end{array}$ & - & 90 & 80 & 10 & 20 & 0 & 0 & 0 & 0 & 0 & 0 \\
\hline \multirow{4}{*}{$\begin{array}{l}\text { Tearing } \\
\text { Axial milling } \\
\text { Transversal } \\
\text { milling }\end{array}$} & - & 10 & 10 & 60 & 35 & 30 & 30 & 0 & 25 & 0 & 0 \\
\hline & - & 85 & 70 & 15 & 25 & 0 & 5 & 0 & 0 & 0 & 0 \\
\hline & - & 15 & 0 & 85 & 90 & 0 & 10 & 0 & 0 & 0 & 0 \\
\hline & $8 \mathrm{~mm}$ & 0 & 20 & 70 & 65 & 30 & 15 & 0 & 0 & 0 & 0 \\
\hline \multirow[t]{2}{*}{ Pin drilling } & $10 \mathrm{~mm}$ & 15 & 15 & 45 & 60 & 40 & 20 & 0 & 0 & 0 & 0 \\
\hline & $12 \mathrm{~mm}$ & 10 & 20 & 55 & 70 & 35 & 10 & 0 & 0 & 0 & 0 \\
\hline Hinge & Through & 35 & 25 & 65 & 60 & 0 & 15 & 0 & 0 & 0 & 0 \\
\hline drilling & Non-through & 40 & 15 & 60 & 65 & 0 & 20 & 0 & 0 & 0 & 0 \\
\hline
\end{tabular}

Where: Bs - B. spiciformis and Jg - J. globiflora.

Comparison between wood species in planing reveals better performance of $B$. spiciformis. Possibly, this result was due to the species J. globiflora having intercrossed grain, which hinders the planing at high feed speed. The surface quality grades obtained in planing are illustrated in Figure 2.

A
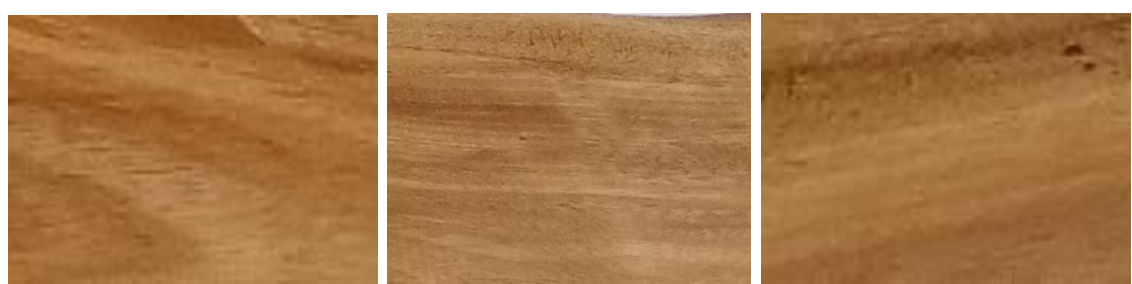

B

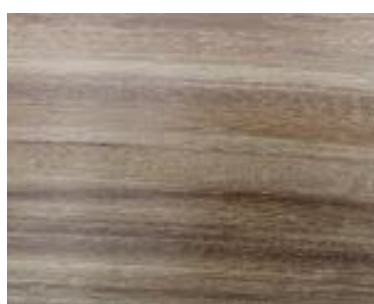

Grade 1

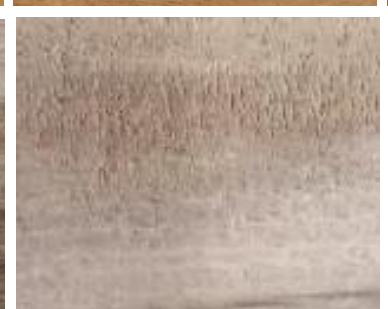

Grade 2

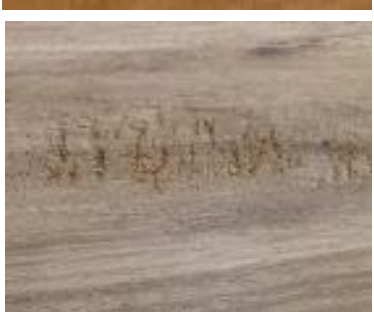

Grade 3

Figure 2. Surface quality grades in planing of B. spiciformis (A) and J. globiflora wood (B) 
The molding operation had a percentage of approved sample above $85 \%$ and rated excellent (grade 1) and good surface quality (grade 2) on the top and side frame (Table 3). In turn, the axial winding frame showed $100 \%$ approval in both species. These operations were performed with different cutting and feeding speeds, all of which were lower in the axial winding frame due to the operation requirement (Table 1). Unlike the other moldings, the winding axial frame is undoubtedly the least delicate due to the orientation of the cutting efforts in relation to the fibers, which favored the observed results. It is noteworthy that, besides the possible effects of wood anatomy, cutting and feeding speeds on the good results obtained in machining operations (Silva et al. 2005; Bustos et al. 2010), the use of tool without wear and good condition of the machines used contributed to the better quality of the machined wood surface.

It should be noted that the wood needs some care for tearing and boring operation. In these operations both species had a similar performance in which the samples were mainly graded 2 , followed by grade 3 . Exceptionally for the species $\mathrm{J}$. globiflora, in the tearing operation, there were samples graded 4 (Table 3 ). This grade occurred in samples whose tearing coincided in the sapwood region and was characterized by the chilling and strong pull-out of the fibers (Figure 4). Despite that, this defect little compromises the acceptability of the species for this operation because it can be eliminated with sanding. In addition, further studies on cutting parameters such as cutting speed and feed speed or changes in tool edge angles may improve this operation.

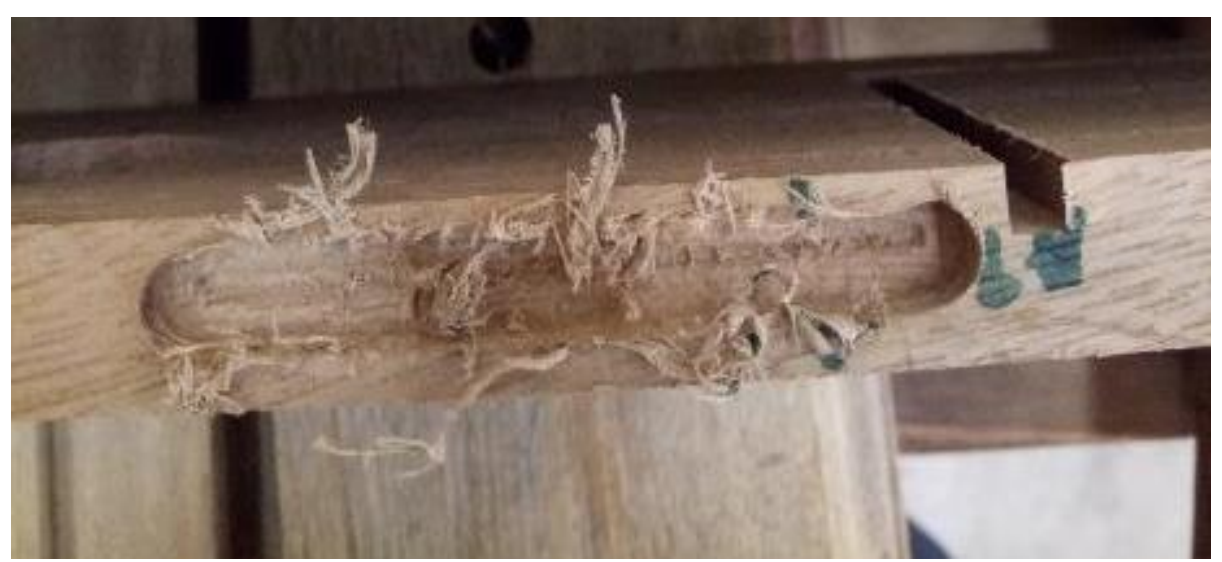

Figure 3. Tear with presence of chills and pullout of the fibers in J. globiflora wood

Raised and chipped grains were the common defects observed during boring. In the through holes the evaluation was made in the exit of the drill. For non-through holes (hinge) were assessed at the bottom of the hole. Although some samples were graded 3 in the pin drilling mainly for the $B$. spiciformis species, these do not afect the final surface quality as they will be eliminated during sanding. Overall, the species performed well against the boring operation.

Axial milling also performed satisfactorily with most samples approved in grade 1, equivalent to the high quality wood surface. Particular emphasis should be given to the cross-milling operation which, despite being performed with orientation of cutting effort perpendicular to the fiber arrangement, the wood of both species performed well, with most of samples lying in the graded 2 (good quality) with a percentage of (85 and 90$) \%$ for B. spiciformis and $\mathrm{J}$. globiflora respectively. According to Silva (2002), the wood profiling, especially against the fibers, allows to really evaluate the machinability of the wood, since it is machined under drastic conditions, and can demonstrate its true potential. In addition, according to the same author for intercrossed grain wood species, such as J. globiflora, it is recommended concurrent milling, ie the workpiece moves in the same direction of rotation of the machine to minimize the machining defects.

The results obtained for machining operations (except the tearing operation) of studied species are similar to those of wood with good machining, such as the african mahogany species (Khaya ivorensis) reported by Carvalho et al. (2010). On the other hand, Table 4 presents the comparison of the average grades results found in the present study for the different machining operations in relation to some species also commonly used in the manufacture of furniture such as Swietenia macrophylla (Mahogany) basic density of $0.530 \mathrm{~g} . \mathrm{cm}^{-3}$, Ocotea porosa (Imbuia) of $0.540 \mathrm{~g} \mathrm{.cm}^{-3}$ and Eucalyptus grandis of 0.510 ${\mathrm{g} . \mathrm{cm}^{-3}}^{-3}$ obtained by Silva (2002).

Although the results presented in Table 4 were not obtained under the same test conditions, the comparison with the species commonly used in furniture manufacture illustrates better performance of $B$. spiciformis and $J$. globiflora species in most of machining operations, which shows the suitability of the species under study for more noble uses such as furniture and frame production. Barcik et al. (2014), Gaff et al. (2015) and Gupta et al. (2017) state that parameters such as density, cutting speed, among others, have a direct proportionality with the roughness of the wood, resulting in the improvement of the machining 
surface quality as they increase. Hernández et al. (2001) and Belleville et al. (2016) reported good machining performance as the density of Picea glauca and Eucalyptus wood increases, respectively. From this point of view, considering the average density of the messassas wood, it can be inferred that it favors the workability and, therefore, the good performance demonstrated in machining operations.

Table 4. Assigned average grades by machining operation for B. spiciformis and J. globiflora, along with Ocotea porosa, Swietenia macrophylla and Eucalyptus grandis.

\begin{tabular}{|c|c|c|c|c|c|}
\hline Machining operation & B. spiciformis & J. globiflora & Imbuia* & Mahogany * & E. grandis ${ }^{*}$ \\
\hline Planing & $2.3(20.2)$ & $1.6(33.9)$ & 3.1 & 1.5 & 2.1 \\
\hline Top frame & $2.0(15.5)$ & $1.9(19.1)$ & 3.8 & 1.7 & 3.2 \\
\hline Side frame & $1.2(25.0)$ & $1.2(30.5)$ & 2.3 & 4.5 & 5.0 \\
\hline Winding axial frame & $1.2(16.4)$ & $1.3(18.8)$ & 1.3 & - & 3.6 \\
\hline Tearing & $2.4(25.4)$ & $2.8(22.9)$ & 2.4 & 3.4 & 2.9 \\
\hline Axial milling & $1.2(22.0)$ & $1.3(31.2)$ & 2.9 & 2.9 & 3.9 \\
\hline Transverse milling & $1.8(16.4)$ & $2.1(16.4)$ & 2.5 & 2.5 & \\
\hline Pin hole & $2.4(14.7)$ & $2.6(12.9)$ & 2.2 & 2.4 & 4.3 \\
\hline Hinge hole & $2.3(11.9)$ & $2.3(15.4)$ & - & - & - \\
\hline
\end{tabular}

${ }^{*}$ Silva, (2002); Numbers in parenthesis represent the coefficient of variation; - absent

\section{Correlations between Machining Operations}

The Spearman's correlation between wood machining operations on B. spiciformis and J. globiflora wood did not show significant correlations in most cases at 1 and $5 \%$ probability. Exceptionally, it was observed that there was a positive correlation between the transverse milling and the top frame operations, besides the side frame and winging axial frame in both species (Figure 4). However, it is important to state that, in general, the correlations found were weak witnessed by the $\mathrm{R}^{2}$ coefficient well below $30 \%$.

The absence or weak correlation between the operations presupposes the non-influence of one operation on the results of the other and may be performed differently from the sequential order adopted in the present research. However, planing is known to be one of the first operations in wood machining.
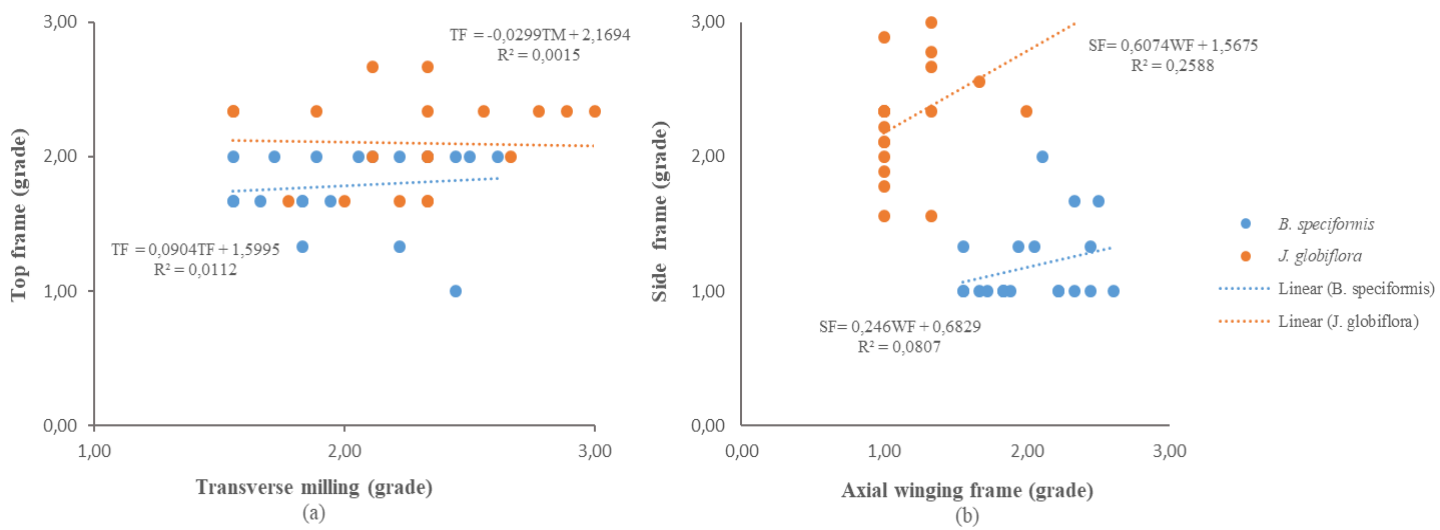

Figure 4. Correlations between top frame $\left(T_{F}\right)$ and transverse milling $\left(T_{M}\right)$ operations (a); and Correlations between side frame $\left(\mathrm{S}_{\mathrm{F}}\right)$ and axial winging frame $\left(\mathrm{W}_{\mathrm{F}}\right)$ operations $(\mathrm{b})$ for species B. spiciformis and J. globiflora wood.

The observed correlations between the operations (Figure 4) may occur due to the possibility of these operators occurring in the same direction relative to the grain direction (Figure 1). There were no relevant literature reports on correlations between these operations. However, studies that aim to verify this trend by varying if the machining parameters in these operations for the same or another target group of species, as well as correlating them with the anatomical properties, are pertinent and needs continued reasearch.

\section{Conclusions}

The wood of species B. spiciformis and J. globiflora presents ease of machining in planing, side frame, top frame, axial and transverse milling, winding axial profiling, tearing, pin and hinge drilling. The surface quality of the machined wood under the test conditions was considered satisfactory and superior for $B$. spiciformis compared to $\mathrm{J}$. globiflora specie. Both B. spiciformis and J. globiflora are suitable for use in the Mozambican furniture industry, especially for furniture and frame production. Thus, 
considering the good performance of the species under study in the different machining operations, there is a possibility to promote forest management activities aimed at improving their health, especially in younger stands, in order to guarantee the good quality raw material for the wood industries.

\section{Acknowledgments}

The authors thank the Ministry of Science and Technology, Higher Education and Technical-Professional of Mozambique for financial support.

\section{References}

Aguilera, A. and H. Muñoz. 2011. Rugosidad superficial y potência de corte en el cepillado de Acacia melanoxylon y Sequoia sempervirens. Maderas. Ciencia y Tecnología 13 (1): 19-28.

Ali A.C; E. Uetimane Jr.; I.A Lhate; N. Terziev. 2008. Anatomical characteristics, properties and use of traditionally used and lesser-known wood species from Mozambique: a literature review. Wood Science and Technology 42(6): 453-472.

ASTM International. 2011. ASTM D 1666-11: Standard method for conducting machining tests of wood and wood base materials. West Conshohocken, PA, USA: ASTM International.

Barcík, S.; M. Gasparík; A. Houka; E. Razumov; Ju; M. Selecky. 2014. Influence of technological factores on the surface quality after miling of thermally modified pine wood. In: Chip and Chipless Woodworking Process 2014: Conference Proceedings, Zvolen, Slovakia. p.11-22.

Belleville, B.; P. Ashley; B. Ozarska. 2016. Wood machining properties of Australian plantation-grown Eucalyptus. Maderas. Ciencia y Tecnología 18 (4): 677-688.

Bila N.F.; R. Luis; P.T.A. Gonçalves; G.I.B. Muñiz; S. Nisgoski. 2018. Wood anatomy of five species from Mozambique and its potential application. Bosque 32(2): 169-177.

Braga, P.O.C; J.R.M. Silva; A. C. Néri; N. Calegário; J.T. LIMA. 2014. Qualidade da superfície de madeira de Coffea arábica. Cerne 20 (1): 21-28.

Brown, J. 1998. Advanced machining tecnology handbook. 2. ed. New York: Mcgraw-hill.

Bustos, A.C.; L.C. Moya; M.J. Lisperguer; M.E. Viveros. 2010. Effect of knife wear on the gluability of planed surfaces of radiata pine. Wood and Fiber Science 42(2): 185-191.

Direção Nacional de Terras e Florestas (DNTF). 2017. Exploração Sustentável da Madeira em Moçambique. Maputo.p.16.

Carvalho, A. M.; B.T.B. Silva; J.V.F. Latorraca. 2010. Avaliação da usinagem e caracterização das propriedades físicas da madeira de Mogno africano (Khaya ivorensis A. Chev.). Cerne 16: 106-114.
Cristovão, L.; I.A. Lhate; A. Grönlund; M. Ekevad; R. Sitoe. 2011. Tool wear for lesser-known tropical wood species. Wood Material Science and Engineering 6 (3): 155-161.

Gaff, M; M. Kvietkova; M. Gašparík; L. Kaplan; S. Barcik. 2015. Effect os selected parameters on the surface waviness in plane milling of thermally modified birch wood. BioResources 10(4): 7618-7626.

Gupta, S.; C.P. Singh; V.S. Klshan-kumar; S. Shukla. 2019. Machining properties of Melia dubia wood. Maderas. Ciencia y Tecnología 21(2): 197-208.

Hernández, R.E.; S. Constantineau; Y. Fortin. 2011. Wood machining properties of poplar hybrid clones from different sites following various drying treatments. Wood and Fiber Science 43(4): 394-411.

Hernández, R.E.; C. Bustos; Y. Fortin; J. Beaulieu. 2001. Wood machining properties of white spruce from plantation forests. Forest Products Journal 51(6): 8288.

Kaplan, L.; M.S. Kvietková; A. Sikora; M. Sedlecky. 2018. Evaluation of the effect of individual paramaters of oak wood machining and their impact on the values of waviness measured by a laser profilometer. Wood Research 63(1): 127-140.

Laina, R; A. Sanz-lobera; A. Villasante; P. lópez-Espí; J. A. M. Rojas; J. Alpuente; R. S. Montero; S. Vignote. 2017. Effect of the anatomical structure, wood properties and machining conditions on surface roughness of wood. Maderas. Ciencia y tecnología 19(2): 203-212.

Lhate, I.A. and L. Cristóvão. 2007. Machining properties of lesser-used wood species from Mozambique. Wood Research 62 (4): 635-644.

Lhate I.A.; C. Cuvilas; N. Terziev; R. Jirjis. 2010. Chemical compositions of traditional and lesser-used species from Mozambique. Wood Material Science Engineering 5 (3-4): 143-150.

Lucas, F.C. 2004. Análise da usinagem da madeira visando à melhoria de processos em indústrias de móveis. Doutorate thesis. Engineering prodution - Santa Caratina Federal University, Florianópolis, Brazil.

Magalhães, T. 2018. Inventário Florestal Nacional. DINAF, Maputo. p.101.

Palermo, G.P.M. 2010. Propriedades e comportamento tecnológico da madeira de Eucalyptus grandis W. Hill ex- Maiden visando a sua utilização em produtos de maior valor agregado. Doutorate thesis. Rio de Janeiro Federal University, Seropédica, Brazil. p.249.

Silva, J.R.M; G.I.B. Muñiz; J.T. Lima; A.F. Bonduelle. 2005. Relações da usinabilidade com a morfologia das fibras da madeira de Eucalyptus grandis Hill Ex. Maiden. Revista Árvore 29(3): 479-487.

Silva, J.R.M. 2002. Relações da usinabilidade e aderência do verniz com as propriedades fundamentais do Eucalyptus grandis hill ex. maiden. Doutorate thesis. Paraná Federal University, Curitiba, Brazil. 
Taylor, J.B.; A.L. Carrano; R.L. Lemaster. 1999. Quantification of process parameters in a Wood sanding operation. Forest Products Journal 49(5): 4146.

Uetimane E. Jr.; M. Jebrane; N. Terziev; G. Daniel. 2018. Comparative wood Anatomy and Chemical Composition of Millettia mosssambicensis and Millettia sthulmannii from Mozambique. BioResources 13(2): 3335-3345.

Uetimane, E. J.r; N. Terziev; G. Daniel. 2009. Wood anatomy of three lesser-known species from Mozambique. IAWA Journal 30(3): 277-291.

Zamarian, E.H.; C.E. Albuquerque; J.L.M. MATOS. 2012. Usinagem da madeira de Bracatinga para uso na indústria madeireira. Revista Floresta 42(3): 631-638.

Vančo, M.; A. Mazán; S. Barcík; L. Rajko; P. Koleda; Z. Vyhnálikova; R.R. Safín. 2017. Impact os selected technological. Technical and material factors on the quality of machined surface at face milling os thermally modified Pine wood. BioResources 12(3): 5140-5154.
Narciso Fernando Bila, Andrade Fernando Egas, and Alberto Fernando Mussana

Department of Forestry Engineering,

Eduardo Mondlane University, Maputo, Mozambique.

Julius Nyerere Avenue, 3453, Main Campus, P.O.Box 257.

Telephone : +258-21-492177/9,

Fax : : 258-21-492176.

Corresponding author

E-mails : bila.narciso@gmail.com; aegas8@gmail.com; klebermussana@gmail.com

Rosilani Trianoski, Márcio Pereira Da Rocha, and Setsuo Iwakiri

Department of Forestry Engineering and Technology, Paraná Federal University, Curitiba, PR, Brazil.

Lothário Meissner Avenue, 632, CEP 80210-170

Telephone : +55 41 3360-4212.

E-mails : rosillani@gmail.com; mprocha01@gmail.com; setsuo.ufpr@gmail.com

José Reinaldo Moreira da Silva

Departamento de Ciências Florestais,

Universidade Federal de Lavras, Lavras, MG, Brasil.

Doutor Sylvio Menicucci Avenue, 1001, CEP 37200-000

Telephone : +55 35 3829-1411.

Email : jreinaldoms@gmail.com 